\title{
Dietary $\beta$-mannanase decreases cloacal temperature of broiler chickens under hot conditions without affecting growth performance
}

El consumo de B-mananasa disminuye la temperatura cloacal de pollos de engorde bajo condiciones de calor sin afectar su rendimiento de crecimiento

O consumo de $\beta$-mananase diminui a temperatura da cloaca do frango de corte em condições de calor sem afetar seu desempenho do crescimento

Tae Sung Yang; Moon Chan Kim; Franco Martinez-Pitargue; Hyeon Seok Choi; Dong Yong Kil*.

Department of Animal Science and Technology, Chung-Ang University, Anseong-si, Gyeonggi-do 17546, Republic of Korea.

(Received: May 15, 2017; accepted: December 4, 2018)

To cite this article:

Yang TS, Kim MC, Martínez-Pitargue F, Choi HS, Kil DY. Dietary $\beta$-mannanase decreases cloacal temperature of broiler chickens under hot conditions without affecting growth performance. Rev Colomb Cienc Pecu 2019; 32(3):184-191.

DOI: https://doi.org/10.17533/udea.rccp.v32n3a03 


\section{Abstract}

Background: High amounts of nonstarch polysaccharides in the diet may increase the amounts of fermentative materials in the hindgut, leading to an increase in fermentative heat production. Dietary $\beta$-mannanase is reported to decrease antinutritional effects of $\beta$-mannans, such as the potential increase of body heat; however, its efficacy on broiler chickens raised under hot climatic conditions has not been investigated. Objective: To investigate the effects of dietary $\beta$-mannanase on growth performance, cloacal temperature, relative lymphoid organ weight, and blood characteristics of broiler chickens raised under hot climatic conditions. Methods: A total of 1,701 1-day-old Ross 308 broiler chickens were randomly allotted to one of three dietary treatments with nine replicates. A basal diet was prepared and added with $\beta$-mannanase at 0.05 or $0.10 \%$ inclusion levels. The experiment was conducted for 30 days. Average room temperature was $28.8 \pm 1.74{ }^{\circ} \mathrm{C}$ and average relative humidity $(\mathrm{RH})$ was $76.1 \pm 11.49 \%$ during the experiment. Results: Growth performance of broiler chickens raised under hot climatic conditions was not affected by $\beta$-mannanase inclusion. Cloacal temperature decreased at the end of experiment (linear, $\mathrm{p}<0.05$ ) with increasing inclusion levels of dietary $\beta$-mannanase. Increasing inclusion levels of $\beta$-mannanase tended to increase (linear, $p=0.076$ ) the relative weight of thymus, but had no effects on the relative weight of spleen and bursa of Fabricius. Blood characteristics were not influenced by dietary $\beta$-mannanase. Conclusion: Increasing inclusion levels of $\beta$-mannanase decrease cloacal temperature; however, it does not directly influence growth performance nor alleviates the heat stress of broiler chickens raised under hot climatic conditions.

Keywords: blood traits; $\beta$-mannanase; broiler; feed enzymes; growth performance; heat stress; lymphoid organs.

\section{Resumen}

Antecedentes: Altas cantidades de carbohidratos no almidonosos en la dieta pueden aumentar la cantidad de materiales fermentativos en el intestino posterior, aumentando la producción de calor fermentativo. La $\beta$-mananasa dietaria disminuye los efectos antinutricionales de los $\beta$-mananos, tales como el potencial incremento de la producción calorica; Sin embargo, no se ha investigado su eficacia en pollos de engorde criados bajo condiciones de calor ambiental. Objetivo: Investigar los efectos de la $\beta$-mananasa en la dieta sobre el crecimiento, la temperatura cloacal, el peso relativo de los órganos linfoides y las características sanguíneas de pollos de engorde criados bajo condiciones climáticas calientes. Métodos: Un total de 1.701 pollos de engorde de 1 día de edad (Ross 308) fueron asignados al azar a uno de tres tratamientos dietarios con nueve repeticiones. A una dieta basal se le adicionó $\beta$-mananasa en niveles de inclusión de 0,05 o 0,10\%. El experimento duró 30 días. La temperatura ambiente durante el experimento fue de $28,8 \pm 1,74{ }^{\circ} \mathrm{C}$ y la humedad relativa de 76,1 $\pm 11,49 \%$. Resultados: La inclusión de $\beta$-mananasa no afecto el rendimiento de los pollos. La temperatura cloacal medida al final del experimento disminuyó (lineal, $\mathrm{p}<0,05$ ) con niveles de inclusión dietarios crecientes de $\beta$-mananasa. Niveles incrementales de $\beta$-mananasa tendieron a aumentar $(\operatorname{lineal}, \mathrm{p}=0,076)$ el peso relativo del timo, pero no hubo efecto sobre el peso del bazo o la bursa de Fabricio. La $\beta$-mananasa no influenció las características de la sangre. Conclusión: Niveles incrementales de $\beta$-mananasa disminuyen la temperatura cloacal, aunque afectan el crecimiento ni alivian el estrés térmico del pollo de engorde criado bajo condiciones climáticas calientes.

Palabras clave: $\beta$-mannanase; características sanguíneas; crecimiento; enzimas exógenas; estrés térmico; órganos linfoides; pollos de engorde; rendimiento.

\section{Resumo}

Antecedentes: Altas quantidades de polissacáridos não amiláceos na dieta podem aumentar as quantidades de materiais fermentativos no intestino posterior, levando a um aumento na produção de calor fermentativo. A $\beta$-mananase dietética é relatada para diminuir os efeitos antinutricionais da $\beta$-manana, tal como o possível aumento da produção de calor; Entretanto, não tem sido investigada a eficácia dela em frangos de corte criados em condições climáticas quentes. Objetivo: Investigar os efeitos da $\beta$-mananase na dieta sobre o desempenho do crescimento, a temperatura cloacal, o peso relativo dos órgãos linfóides e as características de sanguíneas de frangos de corte criados em condições climáticas quentes. Métodos: Um total de 1.701 frangos de corte de um dia de idade (Ross 308) foram distribuídos aleatoriamente em um dos três tratamentos dietéticos com nove repetições. A dieta basal foi preparada e a $\beta$-mananase foi adicionada à dieta basal com níveis de inclusão de 0,05 ou $0,10 \%$. O experimento foi conduzido durante 30 dias. A temperatura ambiente média foi de 28,8 temperatura ahumidade relativa (HR) média foi de $76,1 \pm 11,49 \%$ durante o experimento. Resultados: $\mathrm{O}$ 
desempenho de crescimento dos frangos de corte criados em condições climáticas quentes não foi afetado pelos níveis de inclusão de $\beta$-mananase. A temperatura cloacal medida no final do experimento foi diminuída (linear, $\mathrm{p}<0,05$ ) com níveis crescentes de inclusão de $\beta$-mananase na dieta. $\mathrm{O}$ aumento dos níveis de inclusão da $\beta$-mananase tendeu a aumentar (linear, $\mathrm{p}=0,076$ ) o peso relativo do timo, mas não teve efeitos sobre o peso relativo do baço e da bursa de Fabricius. As características do sangue não foram influenciadas pela $\beta$-mananase dietética. Conclusão: Os níveis crescentes de inclusão de $\beta$-mananase diminuem a temperatura cloacal; entretanto, isso não influencia diretamente o desempenho do crescimento e alivia o estresse térmico dos frangos de corte criados em condições climáticas quentes.

Palavras-chave: $\beta$-mananase; características do sangue; desempenho de crescimento; enzimas alimentares; estresse térmico; frangos de corte; órgãos linfóides.

\section{Introduction}

Nonstarch polysaccharides (NSPs) are considered anti-nutritional factors (ANFs) in poultry diets by increasing digesta viscosity, which is often associated with decreased nutrient digestibility (Mussini et al., 2011; Shastak et al., 2015). Furthermore, NSPs are not digested in the small intestine, passing to the hindgut of poultry. Therefore, diets high in NSPs may increase hindgut fermentation leading to increased heat production (Jósefiak et al., 2004; Choct et al., 2010). Low dietary levels of NSPs or its increased utilization could decrease total heat production of poultry (Nian et al., 2011), which could be of benefit on heat-stressed poultry raised under hot climatic conditions.

Dietary $\beta$-mannan is one of the main NSPs in poultry diets (CVB, 1998). Dietary $\beta$-mannanase, which is an exogenous enzyme that hydrolyses $\beta$-mannans, has been reported to decrease the anti-nutritional effects of $\beta$-mannans, and thus, improve animal productivity (Kong et al., 2011; Kwon and Kim, 2015; Shastak et al., 2015). Similar improvements in the utilization of dietary NSPs by exogenous NSP-degrading enzymes have been widely observed in broiler chickens (Bhuiyan and Iji, 2015; Abdollahi et al., 2016). These positive effects of dietary $\beta$-mannanase may also result in decreased heat loads of poultry by lowering fermentative heat production in the hindgut, which leads to a decrease in heat stress if the poultry is raised under hot climatic conditions. However, the efficacy of dietary $\beta$-mannanase on broiler chickens raised under hot climatic conditions has not been investigated.

Therefore, the present experiment was conducted to investigate the effects of dietary $\beta$-mannanase on growth performance, cloacal temperature, relative lymphoid organ weight, and blood characteristics of broiler chickens raised under hot climatic conditions.

\section{Materials and methods}

\section{Ethical considerations}

All experimental procedures were reviewed and approved by the Animal Care and the Use Committee at Chung-Ang University (IACUC No.: 2016-00108).

\section{Animals and experimental design}

A total of 1,701 1-day-old Ross 308 broiler chickens were obtained from a local hatchery (Yangji Hatchery, Pyeongtaek, Republic of Korea). All chicks were housed in conventional floor pens $(200 \times 230 \times 100 \mathrm{~cm}$; width $\times$ length $\times$ height for each pen). All chicks were randomly allotted to one of three dietary treatments with nine replicates consisting of 63 chicks per replicate. A two-phase feeding program with a starter diet from 0 to 21 days and a grower diet from 22 to 30 days was used in the experiment (Table 1). A basal diet for each growing phase was prepared. All nutrients and energy requirements in the basal diet met or exceeded the nutrient recommendations by the NRC (1994) for broiler chickens. Dietary $\beta$-mannanase (CTCZYME; declared activity of 800,000 unit/kg, CTCbio Inc., Seoul, Republic of Korea) was added to the basal diet at inclusion levels of 0.05 or $0.10 \%$ at the expense of cornstarch. The experimental diets were in a mash form. All birds were provided free access to feed and water throughout the experiment. The experiment lasted for 30 days, covering a hot season of South Korea, from mid-July to the middle of August. Average room temperature was $28.8 \pm 1.74^{\circ} \mathbf{C}$ and average relative humidity was $76.4 \pm 11.49 \%$ during the experiment. 
Table 1. Composition and nutrient content of basal diets (as-fed basis)*.

\begin{tabular}{|c|c|c|}
\hline \multirow[b]{2}{*}{ Item } & \multicolumn{2}{|c|}{ Basal diets } \\
\hline & $\begin{array}{l}1-21 \\
\text { days }\end{array}$ & $\begin{array}{l}22-30 \\
\text { days }\end{array}$ \\
\hline \multicolumn{3}{|l|}{ Ingredients (\%) } \\
\hline Corn & 44.25 & 52.11 \\
\hline $\begin{array}{l}\text { Soybean meal ( } 45 \% \text { crude } \\
\text { protein) }\end{array}$ & 29.20 & 28.20 \\
\hline Wheat & 8.00 & 4.00 \\
\hline $\begin{array}{l}\text { Distillers dried grains with } \\
\text { solubles (DDGS) }\end{array}$ & 4.00 & 3.00 \\
\hline Corn gluten feed & 6.00 & 4.00 \\
\hline Animal fat & 3.66 & 4.29 \\
\hline Monodicalcium phosphate & 1.88 & 1.70 \\
\hline Limestone & 1.54 & 1.40 \\
\hline Salt & 0.30 & 0.30 \\
\hline $99 \%$ Methionine & 0.27 & 0.18 \\
\hline 78\% Lysine-hydrochloric acid & 0.20 & 0.12 \\
\hline $50 \%$ Choline chloride & 0.10 & 0.10 \\
\hline Vitamin-mineral premix ${ }^{* *}$ & 0.20 & 0.20 \\
\hline Sodium bicarbonate $\left(\mathrm{NaHCO}_{3}\right)$ & 0.10 & 0.10 \\
\hline Cornstarch & 0.10 & 0.10 \\
\hline Antioxidant & 0.10 & 0.10 \\
\hline Anticoccidial drug & 0.10 & 0.10 \\
\hline Total & 100.00 & 100.00 \\
\hline \multicolumn{3}{|l|}{ Energy and nutrient content ${ }^{* * *}$} \\
\hline $\operatorname{AME}_{n}(\mathrm{kcal} / \mathrm{kg})$ & 3,000 & 3,050 \\
\hline Crude protein (\%) & 22.55 & 20.57 \\
\hline Lysine (\%) & 1.20 & 1.08 \\
\hline Methionine + Cystine (\%) & 0.99 & 0.83 \\
\hline Calcium (\%) & 1.00 & 0.92 \\
\hline Available phosphorus (\%) & 0.46 & 0.42 \\
\hline
\end{tabular}

* $\beta$-mannanase was included in the diet by replacing the same amounts of cornstarch.

"*Provided per kilogram of the complete diet : vitamin A: 12,500 IU; vitamin D3: 2,500 IU; vitamin E: $20 \mathrm{IU}$; vitamin K3: $2 \mathrm{mg}$; vitamin B1: $2 \mathrm{mg}$; vitamin B2: $5 \mathrm{mg}$; vitamin B6: $3 \mathrm{mg}$; vitamin B12: $18 \mu \mathrm{g}$; folic acid: $1 \mathrm{mg}$; biotin: 50 $\mu$; niacin: $24 \mathrm{mg}$; zinc: $60 \mathrm{mg}$; manganese: $50 \mathrm{mg}$; iron: $50 \mathrm{mg}$; copper: 6 $\mathrm{mg}$; cobalt: $250 \mu \mathrm{g}$; iodine: $1 \mathrm{mg}$; selenium: $150 \mu \mathrm{g}$.

***Calculated values (National Research Council, 1994); AMEn: nitrogencorrected apparent metabolizable energy.

\section{Measurements}

The detailed procedure for measuring growth performance of broiler chickens was reported previously (Kim et al., 2017). In short, body weight (BW) and feed intake (FI) were recorded at the end of the experiment to calculate body weight gain (BWG) and feed conversion ratio (FCR). Cloacal temperature was determined by inserting a digital thermometer (Omron Healthcare Korea Co., Ltd., Seoul, Republic of Korea) $3 \mathrm{~cm}$ into the cloaca of four birds per replicate, randomly selected on days 21 and 30 of the experiment. At the end of the experiment, three birds per replicate with a BW close to the mean BW of the replicates (i.e., 27 birds per treatment) were euthanized by cervical dislocation. Lymphoid organs (namely, thymus, spleen, and bursa of Fabricius) were harvested and weighed. Relative lymphoid organ weights were calculated as lymphoid organ fresh weight $(\mathrm{mg}) /$ chicken BW $(\mathrm{g})$ before slaughter(Liu et al., 2014). Blood samples were collected by heart puncture using serum vacutainer tubes and blood $\mathrm{pH}$ was measured using blood $\mathrm{pH}$ meters (Hanna instruments, Woonsocket, RI, USA). Blood samples for leukocyte profile examination also were collected into EDTA-coated tubes, and the examination was performed immediately with a veterinary blood analyzer (HEMAVET 950FS, Cumbria, UK). The heterophil:lymphocyte ratio (H:L ratio) was used as a stress indicator, and calculated by dividing the number of heterophils by the number of lymphocytes (Gross and Siegel, 1983).

\section{Statistical analysis}

All data were tested for normal distribution and outliers with the UNIVARIATE procedure of SAS (SAS Institute Inc., Cary, NC, USA). No outliers were identified. Afterwards, all data were analyzed by ANOVA in a completely randomized design using the PROC GLM procedure (SAS Institute Inc., Cary, NC, USA). Each replicate was considered as an experimental unit in all data analyses $(n=9$ per treatment). The LSMEANS procedure was used to calculate treatment means. The orthogonal polynomial contrast test was performed to determine linear and quadratic effects of increasing inclusion levels of $\beta$-mannanase in diets on each measurement (Seo et al., 2018). Significance and tendency for statistical tests were set at $\mathrm{p}<0.05$ and $0.05 \leq \mathrm{p} \leq 0.10$, respectively. 
Table 2. Effects of dietary $\beta$-mannanase on growth performance of broiler chickens raised under hot climatic conditions*.

\begin{tabular}{|c|c|c|c|c|c|c|}
\hline \multirow[b]{2}{*}{ Item } & \multicolumn{3}{|c|}{ Dietary $\beta$-mannanase, $\%$} & \multirow[b]{2}{*}{ SEM } & \multicolumn{2}{|c|}{ p-values ${ }^{* *}$} \\
\hline & 0 & 0.05 & 0.10 & & Linear & Quadratic \\
\hline Initial body weight (g) & 42 & 42 & 42 & & & \\
\hline Final body weight (g) & 1,106 & 1,101 & 1,179 & 34.7 & 0.149 & 0.333 \\
\hline Body weight gain (g) & 1,064 & 1,058 & 1,137 & 34.7 & 0.150 & 0.333 \\
\hline Feed intake $(g)$ & 2,098 & 2,045 & 2,111 & 74.0 & 0.905 & 0.517 \\
\hline FCR (g/g) & 1.99 & 1.95 & 1.85 & 0.074 & 0.220 & 0.739 \\
\hline
\end{tabular}

*Data are least squares means of nine replicates per treatment.

${ }^{* *}$ Orthogonal polynomial contrast test for increasing inclusion levels of dietary $\beta$-mannanase.

FCR: Feed conversion ratio.

\section{Results}

\section{Growth performance}

The effects of dietary $\beta$-mannanase on growth performance of broiler chickens raised under hot climatic conditions are presented in Table 2. During the experiment, increasing inclusion levels of dietary $\beta$-mannanase had no effects on final BW, BWG, FI, and FCR.

Cloacal temperature and relative weight of lymphoid organs

The effects of dietary $\beta$-mannanase on the cloacal temperature and relative lymphoid organ weight are presented in Table 3. Cloacal temperature measured at 21 days of age was not affected by inclusion levels of $\beta$-mannanase; however, cloacal temperature measured at 30 days of age was decreased (linear, $\mathrm{p}<0.05)$ with increasing inclusion levels of $\beta$-mannanase. Regarding relative lymphoid organ weight, inclusion levels of $\beta$-mannanase tended to increase (linear, $p=0.076$ ) relative weight of thymus, but had no effects on relative weight of spleen and bursa of Fabricius.

\section{Blood characteristics}

Blood $\mathrm{pH}$ was not affected by dietary inclusion levels of $\beta$-mannanase (Table 4). Increasing inclusion levels of $\beta$-mannanase did not affect total number of heterophils and lymphocytes. Stress index, expressed in $\mathrm{H}: \mathrm{L}$ ratio, was not influenced by the inclusion levels of $\beta$-mannanase.
Table 3. Effects of dietary $\beta$-mannanase on cloacal temperature and relative lymphoid organ weight of broiler chickens raised under hot climatic conditions*.

\begin{tabular}{|c|c|c|c|c|c|c|}
\hline \multirow[b]{2}{*}{ Item } & \multicolumn{3}{|c|}{$\begin{array}{c}\text { Dietary } \\
\beta \text {-mannanase, } \%\end{array}$} & \multirow[b]{2}{*}{ SEM } & \multicolumn{2}{|c|}{ p-values ${ }^{* *}$} \\
\hline & 0 & 0.05 & 0.10 & & Linear & Quadratic \\
\hline \multicolumn{7}{|c|}{$\begin{array}{l}\text { Cloacal } \\
\text { temperature } \\
\left({ }^{\circ} \mathbf{C}\right)\end{array}$} \\
\hline 21 day & 41.8 & 41.7 & 41.8 & 0.10 & 0.762 & 0.310 \\
\hline 30 day & 42.5 & 42.2 & 42.2 & 0.10 & 0.029 & 0.301 \\
\hline \multicolumn{7}{|l|}{$\begin{array}{l}\text { Relative } \\
\text { lymphoid }\end{array}$} \\
\hline \multicolumn{7}{|l|}{$\begin{array}{l}\text { organ } \\
\text { weight }^{* * *}\end{array}$} \\
\hline Thymus & 0.99 & 0.96 & 1.22 & 0.087 & 0.076 & 0.189 \\
\hline Spleen & 1.17 & 1.47 & 1.38 & 0.138 & 0.295 & 0.248 \\
\hline $\begin{array}{l}\text { Bursa of } \\
\text { Fabricius }\end{array}$ & 1.24 & 1.36 & 1.32 & 0.272 & 0.843 & 0.802 \\
\hline
\end{tabular}

"Data are least square means of nine replicates per treatment.

** Orthogonal polynomial contrast test for increasing inclusion levels of dietary $\beta$-mannanase.

"*** Relative lymphoid organ weight was calculated as lymphoid organ fresh weight $(\mathrm{mg}) /$ chicken body weight $(\mathrm{g})$ before slaughter.

\section{Discussion}

As a NSPs-degrading enzyme, $\beta$-mannanase catalyses the random hydrolysis of the $\beta-1,4-$ mannosidic linkages in $\beta$-mannans (McCleary, 1988). Hydrolysis of $\beta$-mannans in broiler diets can decrease its anti-nutritive effects by reducing the viscosity of digesta, thus, increasing nutrient utilization, especially 
Table 4. Effects of dietary inclusion of $\beta$-mannanase on blood traits of broiler chickens raised under hot climatic conditions*.

\begin{tabular}{lccccccc}
\hline & \multicolumn{3}{c}{$\begin{array}{c}\text { Dietary } \\
\text { B-mannanase, \% }\end{array}$} & & \multicolumn{2}{c}{ p-values $^{* *}$} \\
\cline { 2 - 4 } Item & $\mathbf{0}$ & $\mathbf{0 . 0 5}$ & $\mathbf{0 . 1 0}$ & SEM & Linear & Quadratic \\
\hline Blood pH & 7.1 & 7.2 & 7.2 & 0.04 & 0.432 & 0.516 \\
$\begin{array}{l}\text { Heterophils } \\
(\mathrm{K} / \mu \mathrm{L})\end{array}$ & 7.4 & 9.5 & 9.6 & 1.25 & 0.220 & 0.509 \\
$\begin{array}{l}\text { Lymphocytes } \\
(\mathrm{K} / \mu \mathrm{L})\end{array}$ & 15.8 & 14.9 & 16.0 & 1.05 & 0.887 & 0.423 \\
$\mathrm{H}:$ L ratio $^{* * *}$ & 0.45 & 0.59 & 0.59 & 0.059 & 0.116 & 0.340 \\
\hline
\end{tabular}

"Data are least square means of nine replicates per treatment.

"* Orthogonal polynomial contrast test for increasing dietary inclusion levels of $\beta$-mannanase.

"** The heterophil:lymphocyte $(\mathrm{H}: \mathrm{L})$ ratio was used as a stress index, calculated by dividing the number of heterophils by the number of lymphocytes (Gross and Siegel, 1983).

in the upper part of the gastrointestinal tract (GIT; Hussain et al., 2012; Lee et al., 2018). Accordingly, some studies have indicated that dietary $\beta$-mannanase improves growth performance of broiler chickens (Jackson et al., 2004; Cho and Kim, 2013), whereas other studies showed no beneficial effects (Ouhida et al., 2002). In the present experiment, dietary inclusion of $\beta$-mannanase had no effects on broiler performance. However, positive effects of $\beta$-mannanase in previous experiments cannot be directly compared with those observed in the present study, because the former experiments raised broiler chickens under thermoneutral conditions. The reason for our broiler performance results is not clear. To the best of our knowledge, no reports have evaluated the efficacy of dietary $\beta$-mannanase in broiler chickens raised under hot climatic conditions. Jackson et al. (2004) stated that the positive effects of $\beta$-mannanase are associated with a reduction of digesta viscosity, thus improving energy metabolism. Although not measured in this study, it appears that reduction in digesta viscosity and possible improvement in energy metabolism by $\beta$-mannanase were too little to improve growth performance of broilers.

Several experiments have been conducted to find effective nutritional regimens for mitigating heat stress on broiler chickens, such as dietary inclusion of zinc (Barlet and Smith, 2003), tocopherol (Niu et al., 2009), probiotics, and prebiotics (Sohail et al., 2012). However, inconsistent results have been reported to date. In the present experiment we hypothesized that dietary $\beta$-mannanase could decrease heat loads in broilers raised under hot conditions because it could decrease the amount of fermentable materials in the GIT, therefore reducing fermentative heat production. This hypothesis was partly confirmed: there was a decrease of cloacal temperature at 30 days of age by feeding $\beta$-mannanase. However, cloacal temperature measured at 20 days was not affected by dietary $\beta$-mannanase. This was probably due to differences in body temperature and FI between both ages. However, decreased cloacal temperature from $\beta$-mannanase supplementation was not associated with improved broiler performance. Apparently, the extent of reduction in cloacal temperature was too small to affect performance. Furthermore, the reason for the small reduction in cloacal temperature by dietary $\beta$-mannanase could be the relatively small proportion of heat from intestinal fermentation compared with the total heat production in broilers (Józefiak et al., 2004).

Lymphoid tissues play a vital role in avian immunity. The lymphoid system consists of the central (i.e., bursa of Fabricius and thymus) and peripheral (i.e., spleen, lymph nodes and bone marrow) lymphoid organs (Davison et al., 2008). Thus, the relative lymphoid organ weight is often considered as a measure of immunity in poultry (Pope, 1991). It was reported that relative lymphoid organ weight decreases in broiler chickens exposed to heat stress, indicating decreased immunity (Quinteiro-Filho et al., 2010). Dietary $\beta$-mannanase has been reported to act as a possible immune stimulator because mannanoligosaccharides, produced from $\beta$-mannan degradation in the GIT, improve the immune response in animals (Zou et al., 2006). Likewise, Zangiabadi and Torki (2010) reported that $\beta$-mannanase increased antibody responses to Newcastle vaccination in broiler chickens. In addition, Jackson et al. (2003) reported that $\beta$-mannanase decreased pathogenic lesions in the GIT of broilers challenged with Eimeria spp. and Clostridium perfringens. In the present experiment, we observed a tendency for increased relative weight of thymus with increasing inclusion of $\beta$-mannanase. This result agrees with Zou et al. (2006) who reported that dietary $\beta$-mannanase increases the relative weight of thymus of broiler chickens. On the other hand, Zangiabadi and Torki (2010) reported that $\beta$-mannanase have no effects 
on the relative weight of thymus, bursa of Fabricius, and spleen under thermoneutral conditions, although the antibody responses to Newcastle vaccination were affected by $\beta$-mannanase. It is not clear why the changes in relative lymphoid organ weight in response to $\beta$-mannanase varied with environmental temperature; however, it could be related to different immune responses and stimulation of broilers raised under different thermal conditions.

Blood $\mathrm{pH}$ is often increased in poultry raised under heat stress because increasing panting behavior increases bicarbonate loss (Borges et al., 2004). However, we found no significant effects of $\beta$-mannanase on blood $\mathrm{pH}$ of broilers raised under hot climatic conditions. In addition, blood $\mathrm{H}$ : L ratio is often used as a stress index in poultry exposed to various stressors, including heat stress (Gross and Siegel et al., 1983). In the present study, however, the $\mathrm{H}: \mathrm{L}$ ratio in the blood was not affected by dietary $\beta$-mannanase. These results could reflect a very small change in body temperature of broilers fed $\beta$-mannanase.

In conclusion, dietary $\beta$-mannanase decreases cloacal temperature and increases relative thymus weight of broiler chickens raised under hot climatic conditions. However, these beneficial effects do not directly influence growth performance of broiler chickens raised in hot conditions.

\section{Acknowledgements}

This research was supported by the Chung-Ang University research grant in 2018.

\section{Conflicts of interest}

The authors declare they have no conflicts of interest with regard to the work presented in this report.

\section{References}

Abdollahi MR, Hosking BJ, Ning D, Ravindran V. Influence of palm kernel meal inclusion and exogenous enzyme supplementation on growth performance, energy utilization, and nutrient digestibility in young broilers. Asian-Australas J Anim Sci 2016; 29:539-548.
Bartlett JR, Smith MO. Effects of different levels of zinc on the performance and immunocompetence of broilers under heat stress. Poult Sci 2003; 82:1580-1588.

Bhuiyan MM, Iji PA. Energy value of cassava products in broiler chicken diets with or without enzyme supplementation. AsianAustralas J Anim Sci 2015; 28:1317-1326.

Borges SA, Fischer da Silva AV, Majorka A, Hooge DM, Cummings KR. Physiological responses of broiler chickens to heat stress and dietary electrolyte balance (sodium plus potassium minus chloride, milliequivalents per kilogram). Poult Sci 2004; 83:1551-1558.

Centraal Veevoeder Bureau (CVB). Veevoedertalel (Feeding value of feed ingredients). Centraal Veevoeder Bureau, Runderweg 6, Lelystad, The Netherlands; 1998.

Cho JH, Kim IH. Effects of $\beta$-mannanase supplementation in combination with low and high energy dense diets for growing and finishing broilers. Livest Sci 2013; 154:137-143.

Choct M, Dersjant-Li Y, McLeish J, Peisker M. Soy oligosaccharides and soluble non-starch polysaccharides: a review of digestion, nutritive and anti-nutritive effects in pigs and poultry. Asian-Australas J Anim Sci 2010; 23:1386-1398.

Davison TF, Kaspers B, Schat KA. Avian immunology. Cambrige, MA: Academic Press; 2008.

Gross WB, Siegel HS. Evaluation of the heterophil/lymphocyte ratio as a measure of stress in chickens. Avian Dis 1983;27:972-979.

Hussain M, Rehman AU, Khalid MF. Feeding value of guar meal and the application of enzymes in improving nutritive value for broilers. Worlds Poult Sci J 2012; 68:253-268.

Jackson ME, Anderson DM, Hsiao HY, Mathis GF, Fodge DW. Beneficial effect of $\beta$-mannanase feed enzyme on performance of chicks challenged with Eimeria sp. and Clostridium perfringens. Avian Dis 2003; 47:759-763.

Jackson ME, Geronian K, Knox A, McNab J, McCartney E. A dose-response study with the feed enzyme $\beta$-mannanase in broilers provided with corn-soybean based diets in the absence of antibiotic growth promoters. Poult Sci 2004; 83:1992-1996.

Józefiak D, Rutkowski A, Martin SA. Carbohydrate fermentation in the avian ceca: a review. Anim Feed Sci Technol 2004; 113:1-15.

Kim JH, Jung H, Pitargue FM, Han GP, Choi HS, Kil DY. Effect of dietary calcium concentrations in low non-phytate phosphorus diets containing phytase on growth performance, bone mineralization, litter quality, and foodpad dermatitis incidence in growing broiler chickens. Asian-Australas J Anim Sci 2017; 30:979-984.

Kong C, Lee JH, Adeola O. Supplementation of $\beta$-mannanase to starter and grower diets for broilers. Can J Anim Sci 2011; 91:389-397.

Kwon WB, Kim BG. Effects of supplemental beta-mannanase on digestible energy and metabolizable energy contents of copra expellers and plam kernel expellers fed to pigs. Asian-Australas J Anim Sci 2015; 28:1014-1019. 
Lee BB, Yang TS, Goo D, Choi HS, Pitargue FM, Jung H, Kil DY. Effects of dietary $\beta$-mannanase supplementation on the additivity of true metabolizable energy values for broiler diets. Asian-Australas J Anim Sci 2018; 31:564-568.

Liu LL, He JH, Xie HB, Yang YS, Li JC, Zou Y. Resveratrol induces antioxidant and heat shock protein mRNA expression in response to heat stress in black-boned chickens. Poult Sci 2014; 93:54-62.

McCleary BV. $\beta$-D-mannanase. Method Enzymol 1988; 160:596-610.

Mussini FJ, Coto CA, Goodgame SD, Lu C, Karimi AJ, Le JH, Waldroup PW. Effect of $\beta$-mannanase on broiler performance and dry matter output using corn-soybean meal based diets. Int J Poult Sci 2011; 10:778-781.

Nian F, Guo YM, Ru YJ, Li FD, Peron A. Effect of exogenous xylanase supplementation on the performance, net energy and gut microflora of broiler chickens fed wheat-based diets. AsianAustralas J Anim Sci 2011; 24:400-406.

Niu ZY, Liu FZ, Yan QL, Li WC. Effects of different levels of vitamin $\mathrm{E}$ on growth performance and immune responses of broilers under heat stress. Poult Sci 2009; 88:2101-2107.

National Research Council. Nutrient Requirements of Poultry. $9^{\text {th }}$ rev. edn. National Academy Press, Washington, DC. 1994.

Ouhida I, Perez JF, Anguita M, Gasa J. Influence of $\beta$-mannase on broiler performance, digestibility, and intestinal fermentation. J Appl Poult Res 2002; 11:244-249.
Pope CR. Pathology of lymphoid organs with emphasis on immunosuppression. Vet Immunol Immunopathol 1991; 30:31-44.

Quinteiro-Filho WM, Ribeiro A, Ferraz-de-Paula V, Pinheiro ML, Sakai M, Sá LRM, Ferreira AJP, Palermo-Neto J. Heat stress impairs performance parameters, induces intestinal injury, and decreases macrophage activity in broiler chickens. Poult Sci 2010; 89:1905-1914.

Seo S, Jeon S, Ha JK. Editorial - Guidelines for experimental design and statistical analyses in animal studies submitted for publication in the Asian-Australasian Journal of Animal Sciences. Asian-Australas J Anim Sci 2018; 31:1381-1386.

Shastak Y, Ader P, Feuerstein D, Ruehle R, Matuschek M. $\beta$-mannan and mannanase in poultry nutrition. Worlds Poult Sci J 2015; 71:161-174.

Sohail MU, Hume ME, Byrd JA, Nisbet DJ, Ijaz A, Sohail A, Shabbir MZ, Rehman H. Effect of supplementation of prebiotic mannan-oligosaccharides and probiotic mixture on growth performance of broilers subjected to chronic heat stress. Poult Sci 2012; 91:2235-2240.

Zangiabadi H, Torki M. The effect of $\beta$-mannanase-based enzyme on growth performance and humoral immune response of broiler chickens fed diets containing grade levels of whole dates. Trop Anim Health Prod 2010; 42:1209-1217.

Zou XT, Qiao XJ, Xu ZR. Effect of $\beta$-mannanase (Hemicell) on growth performance and immunity of broilers. Poult Sci 2006; $85: 2176-2179$ 